latter with black shafts, and the spatulate terminations of the two centre feathers largely tipped with black; lores and lengthened earcoverts black, the latter bounded above by a narrow line of blue; beneath the eye a narrow streak of greyish-white, bounded aboye by a finer streak of blue; under surface very pale green, becoming of a still paler and more buffy hue on the vent; on the centre of the breast a few lanceolate pendent feathers of a deep velvety black, narrowly bordered with pale blue; bill black; feet brownish-black. Total length, $15 \frac{1}{2}$ inches; bill, 2 ; wing, $5 \frac{1}{4}$; tail, $8 \frac{5}{8}$; tarsi, $1 \frac{1}{8}$. or Hab. Guatemala.

\title{
On the Anatomy of the Great Anteater
}

(MYRMECOPHAGa Jubata).

By Professon Owen, F.R.S., V.P.Z.S.

Professor Owen read a paper on the Anatomy of the Great Anteater (Myrmecophaga jubata). The animal dissected was a fullgrown female ; it was received at the Gardens September 29, 1853, and died July 6, 1854. It weighed $62 \mathrm{lbs}$.; the weight of the brain was $3 \mathrm{oz}$. avoir. The nipples were two in number, post-pectoral in position; the vulva and vent opened by a common cloacal aperture. The integument was thick; well-developed dermal muscles attached it to parts of the skeleton: the extent and attachments of these were described. The position of the viscera on opening the abdominal cavity was detailed. The intestinal canal is supported by one broad fold of peritoneum, as in reptiles. A long narrow continuous gland extends along the base line of the mesenteric part of the fold, and a parallel series of detached glands along the mesocolic part. Other modifications of the peritoneum were described in relation to the support and connection of other viscera. The stomach consisted of two parts, a cardiac or membranous, and a pyloric or muscular part. The cardiac part is a subglobular cavity, measuring when distended 9 inches in its longest diameter, 7 inches in depth from the cardia, to the left of which the cavity bulges about 4 inches. The circumference of the cavity is 18 inches. The pyloric part is 3 inches in both longitudinal and vertical diameter, $2 \frac{1}{2}$ inches across ; its muscular part is so thick that it may be called a gizzard: it has not however the thick callous epithelial lining of a true ornithic gizzard.

The lining membrane of the stomach, as compared with that of the cesophagus, becomes more vascular and is furnished with a thinner epithelium at the cardiac orifice; but the lining membrane for some distance from that orifice, and between it and the entry to the gizzard, is smoother and covered by a thicker layer of epithelium than in the rest of the cardiac cavity, where the ordinary vascular villous gastric surface prevails : the one modification passes insensibly into the other. When fully distended, the cardiae cavity is smooth; as it contracts, the lining membrane falls into rugæ, very minute and irregular near the cardia, thicker and larger at the greater curvature, and assuming a longitudinal direction as they approach and converge towards the 
entry to the gizzard: at this part the folds were ten in number. In the distended stomach of the female Anteater the transverse diameter of the aperture was 1 inch 3 lines; its vertical diameter from 3 to 4 lines; the distance from it to the cardia, 3 inches.

is In the smaller male Anteater, subsequently dissected, the gizzard was 2 in. 3 lines in length and 2 in. 9 lines in depth.

Vertically and longitudinally bisected, the cavity of the gizzard appeared as a gently bent canal about a line in diameter, suddenly expanding near the pylorus to receive a valvular prominence from the upper muscular wall, which projected towards that opening. The vertical thickness of the muscular wall above the canal was 1 inch 10 lines, below the canal 1 inch.

In the female Anteater Prof. Owen divided the gizzard, previously injected and distended with alcohol. When the gizzard was divided vertically and transversely the cavity presented a crescentic figure, with the horns directed upwards, on each side a large fleshy protuberance which descended into the cavity. On the lower part of the protuberance are three or four thick angular longitudinal ridges, which fit into the interspaces of similar ridges along the lower part of the cavity. The epithelium of the protuberance is thicker than that of the rest of the cavity, concealing in a greater degree, but not wholly, the vaseularity of the subjacent injected membrane: the cellulo-vascular layer uniting the mucous with the muscular coats is most abundant at the walls of the gizzard opposite the protuberance. The thickness of the muscular wall, from the upper part of the gizzard to the bottom of the protuberance, is 2 inches, that of the lower wall of the gizzard 6 lines : the difference of thickness here, as compared with the same part in the smaller Anteater's stomach, is due to the more contracted state of the gizzard in the latter animal.

to On exposing the pylorus from the duodenal side, it presents the form of a crescentic aperture 1 inch in diameter, but reduced to a transverse figure by the pressure of the upper protuberance against its inferior thickened ridge : the mucous membrane of both parts is produced into longitudinal wavy rugæ. A second pylorus might be described where these ruge abruptly terminate and where the smooth surface of the duodenum begins : this aperture presents a full oval form, 1 inch 2 lines by 9 lines, when that intestine is distended.

The length of the animal, from the muzzle to the vent, was 4 feet 7 inches; the length of the head, 14 inches; of the tail, 33 inches. The length of the intestinal canal was 34 feet, the small intestines measuring 30 feet. The ileum, with a circumference of 1 inch 9 lines, rapidly expands at its termination to form the colon, without any crecal beginning of the latter gut. This presents a circumference of $9 \frac{1}{2}$ inches near its commencement, and gradually decreases to a circumference of 6 inches at the rectum. The inner surface of the first. half of the small intestines is smooth and even; the last half, or ileum, is characterized by a single continuous longitudinal fold of the mucous membrane from 2 to 3 lines in breadth, extending along the side of the gut opposite the attachment of the mesentery. The modifications of the colon and rectum were described. 
in The iweight of the liver was 28 oz.ch that of the spleen, $2 \mathrm{loz}$. 6 drachms ; that of the pancreas, 2 oz.: the form and structure of these viscera and of the gall-hladder were describedar The renal and generative organs were next referred to. 291 The disposition of the pleura in the thorax, and the form and structure of the thoracic viscera were detailed $\mathrm{A}$ peculiarity was noticed in the right auricle of the heart: the entry of the anferior cava was guarded as usual by the eustachian valve, the homologue of the posterior of the two semilunar valves which guard the communication between the sinus and the auricle in the heart of Reptiles; in the great Anteater there is a narrower valvular fold or ridge on the opposite side of the orifice of the inferior cava, answering to the anterior valve in the Reptiles' auricle, and a ridge is continued from both valves in the Anteater, towards the opening of the superior cava. $t$

Of the salivary glands of the Anteater the submaxillary pair were those most developed and modified to supply the unusual quantity of adhesive saliva with which the long, slender and moveable tongue is bedewed: these glands extended over the fore part of the neck and chest, and were upwards of 16 inches in length and 2 inches in thickness.

The parotid gland retained its ordinary proportional size and relative position. The sublingual gland was represented by an extensively diffused thin layer of follicles, opening by many small pores upon the inner surface of the mouth. The labial glands were small,
as were also the tonsils.

The muscles of the jaws were described.

Is The cavity of the mouth is susceptible of great dilatation, and presents the peculiarity of being extended far back beyond the root of the tongue. The author accordingly defines, in his description, a postlingual and a prelingual part of the mouth. $A$ hard longitudinal cartilaginous ridge projects downwards into the mouth from the inner side of each ramus of the jaw. The author conceives that the termites may be crushed bo the action or pressure of the tongue against those callous ridges, which seem to oceupy the place of teeth. A fossa descends between the epihyals, which theauthor called the epihyal pouch. The hyoid arch has no immediate connection with the tongue, but is situated far behind the tongue, preserving its usual relations with the larynx.

The thyroid is ossified; the cricoid and arytenoids are cartilaginous. The total length of the nasal passages is 22 inches, the last 8 inches being muscular and membranous, and extended backwards beyond the base of the skull, where the canals terminate in most other mammals.

The antero-posterior diameter of the base of the tongue was $3 \frac{1}{2}$ inches, it rapidly diminishes to a cylindrical form, with a diameter of 8 lines, and is thus continued for 18 inehes, gradually decreasing to its obtuse apex, which is 1 line in breadth? This long cylindrical tongue is composed almost wholly of 'museutar fibres, and covered by a smooth epithelium; the only papille are two fossulate ones (papilla 
vallata) on the dorsum, about 2 inches in advance of the frenum; the muscles of the tongue and their action were minutely described; Ialso those of thellarynx and pharynx.

The brain, which weighed only 3 oz., presented a narrow, elongated, depressed form, the back part of the cerebral hemispheres resting against, but not overlapping, the cerebellum. to The hemispheres showed a few symmetrical convolutions; they were united by a darge corpus callosum: the olfactory lobes are very large and hollow. Many plexuses and other peculiarities of the vascular system were noticed.

This memoir will appear, illustrated with numerous figures, in the Transactions of the Society.

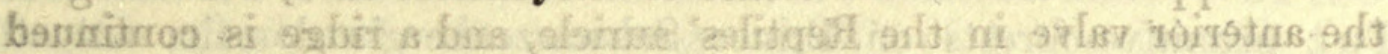

-quinescriptions of Two New TaNagers in the British Museum. By Philip Lutley Sclater, M.A.

1. Chlorospingus melanotis, Sclater. C. supra nigro-plumbeus, dorso imo brunnescentiore : alis caudaque brunnescentibus, illis penitus nigricantibus : loris et capitis lateribus cum regione auriculari nigris: subtus pallide ochraceo-rufus, mento summo nigricante; ventre medio dilutiore: rostro nigro: pedibus pallidis.

Long. tota $5 \cdot 25$ poll., alæ $2 \cdot 5$, caudæ $2 \cdot 25$. baslg biforisg orl $\mathrm{T}$

Hab. in Nova Grenada. Mus. Brit.

Obs. Species rostro et forma Chlorospingo atropileo similis, sed ab hoc et alîs hujus generis colore corporis inferi ochraceo-rufo facile distinguenda.

This little species, of which there are two examples in the National Collection, both apparently Bogota skins, differs from all its congeners in the colouring of the lower surface of the body, which is of a pale reddish buff, growing much whiter in the middle of the belly. Above the plumage is lead-coloured, with a greenish tinge superinduced towards the lower part of the back. The wings and tail are brown, with slight greenish edgings; the ear-coverts and whole side of the face are black.t In the second specimen, apparently not so mature, there is a light-coloured spot on the front, just above the nostrils. rthe bill of this species agrees with that of Chlorospingus atropileus, (Lafr.), in size, but is rather straighter in form, as in C. verticalis, (Lafr.).

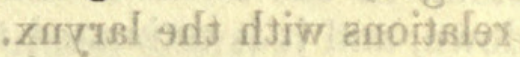

2. TACHYPHonus XaNTHopygius, Sclater. T. nigro-cinereus, subtus dilutior axillis et tectricibus subalaribus albis: dorso brot postico citreo-fiavo ${ }^{2}$ rostro et pedibus nigris.

Long. tota $5 \cdot 8$, alæ $3 \cdot 1$, caudæ $2 \cdot 5$.

Hab. in Nov. Grenada. Mus. Brit.

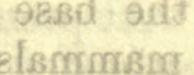
ismingris

This bird seems intermediate between Tachyphoms and Pyranga, and might be placed in either of these groups, The white axillary feathers point to the former genus, the yellow rump to the latter. The bill, however, is more compressed than is usual in Pyranga, and agrees nearly with that of Tachyphonus coronatus, (Vieill,). The upper 


\section{$2 \mathrm{BHL}$ Biodiversity Heritage Library}

Owen, Richard. 1855. "On the anatomy of the Great Anteater (Myrmecophaga Jubata)." The Annals and magazine of natural history; zoology, botany, and geology 16, 374-377. https://doi.org/10.1080/037454809496421.

View This Item Online: https://www.biodiversitylibrary.org/item/19432

DOI: https://doi.org/10.1080/037454809496421

Permalink: https://www.biodiversitylibrary.org/partpdf/30117

\section{Holding Institution}

Natural History Museum Library, London

\section{Sponsored by}

Natural History Museum Library, London

\section{Copyright \& Reuse}

Copyright Status: Public domain. The BHL considers that this work is no longer under copyright protection.

This document was created from content at the Biodiversity Heritage Library, the world's largest open access digital library for biodiversity literature and archives. Visit BHL at https://www.biodiversitylibrary.org. 